\title{
伝統的建造物群保存地区における街路舗装の現状と課題 EXISTING CONDITIONS AND PROSPECTS OF THE STREET PAVEMENT IN PRESERVATION DISTRICTS FOR GROUPS OF TRADITIONAL BUILDINGS
}

\author{
中村遥子*, 黒田乃生** \\ Haruko NAKAMURA and Nobu KURODA
}

\begin{abstract}
Street Pavement in Preservation Districts for Groups of Traditional Buildings are required a conservation point of view in addition to the general aspects such as design and function. The purpose of this study is to clarify the existing conditions and problems of street pavements in Preservation Districts for Groups of Traditional Buildings. Through the questionnaire, interview to municipalities and onsite survey, following points were indicated. More than $80 \%$ use asphalt, and second most are natural stones. Most municipalities do not have clear strategies for pavements. Vague concepts such as "traditional image" and "harmony to the character of the area" are prior to the historic evidence. From the conservation point of view, it is recommended that the designs of street pavements refer to the existing historic evidence. As for the most area with little evidence, street pavement should be less represented rather than using many pompous materials, and it is leaded to the appropriate street landscapes.
\end{abstract}

Keywords : Street Pavement, Preservation Districts for Groups of Traditional Buildings, Design Concept 街路舗装，伝統的建造物群保存地区，整備コンセプト

\section{1. はじめに}

街路景観は建築のファサード、街路樹など多様な要素で構成され ているが、中でも路面は重要で、舗装材料の選択は空間の質を大き

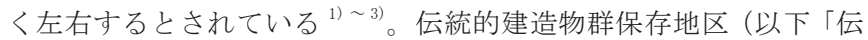
建地区」）の制度は全国各地に残る歴史的な集落・町並みの保存を 目的とし、周囲の環境も含めて保存対象とすることができる。街路 に関して伝統的建造物群保存地区協議会では地区毎の独自の方法に よる街路の歴史的風致との調和を求めているが ${ }^{4)}$ 、伝建地区制度関 連法令において、街路整備・舗装整備に関寸る具体的な提言や規制 はなく、「歴史風」という理由で過去に用いられていない石敷きが 安易に施工されるという問題点も指摘されている ${ }^{5)}$ 。伝建地区にお ける街路舗装には通常の街路舗装に要求されるデザイン・機能の視 点に加え、文化財保護の視点が求められる。

街路景観における舗装に関する研究は、材料について述べている もの ${ }^{6)}$ 、景観・安全などの評価実験を行っているもの ${ }^{7)}$ 、道路景観 の価值を定量的、定性的に評価したもの ${ }^{8), 9)}$ 、空間構成について言 及したもの ${ }^{10)}$ 等があるが、歴史的町並み、特に伝建地区の舗装に ついて網羅的に把握した研究はない。

本研究では、まず全国の伝建地区の街路整備の現状と問題点の傾 向を把握し、次に事例調查から伝建地区における具体的な舖装整備 の問題点を明らかにし、その要因を把握した。最後に今後の伝建地 区の街路景観形成における舗装整備の方向性を考察した。

\section{2. 研究の方法}

伝建地区内の街路における舗装整備について把握するために、平 成 20 年（2008） 8 月時点で重要伝統的建造物群保存地区（以下「重 伝建地区」）に選定されていた 82 地区と伝建地区の都市計画決定 がされていた 1 地区（福岡県黒木町黒木）合わせて 83 地区の保存 計画における街路整備に関する方針を把握し、担当者にアンケート 調查を行なった。さらに、アンケートで回答があった伝建地区のう ち、街路舗装の文化財保護の視点から 4 つの段階に該当する 4 地区 および現状の問題が多いとされた 1 地区、計 5 地区を対象とし、担 当者へのヒアリングおよび現地調查を行った。

\section{3. 伝統的建造物群保存地区保存計画における街路整備の方針}

伝建地区ではそれぞれが伝統的建造物群保存地区保存計画（以下 「保存計画」）を有しており、保存の基本方針、保存地区の環境整備 計画等が定められている。8 8 地区の保存計画から、街路整備に関 する記述を確認した。

\section{（1）環境物件、工作物の指定}

15 地区（18\%）で石畳、小路などの街路が工作物、環境物件に 指定されていた ${ }^{11}$ 。指定の名称は石畳、路地、街道、旧道、古道 など多様である。黒木町黒木では石段、石畳が 28 件工作物に、長 崎市南山手では 36 件の石段・石畳が環境物件に指定されている。 三好市東祖谷では里道が 6 件、合計約 $3 \mathrm{~km}$ が環境物件に指定され
$*$ 特許庁審查業務部 修士 (学術)
$* *$ 筑波大学大学院人間総合科学研究科 准教授 $\cdot$ 博士 (農学)
Trademark, Design and Administrative Affairs Department, Japan Patent Office Assoc. Prof., Graduate School of Comprehensive Human Sciences, University of Tsukuba, Ph. D. in Agriculture 
ている。また、竹富町竹富では、保存整備計画で街路の重要性が強 調されているが、環境物件および工作物の指定はない。

\section{（2）保存計画の内容}

83 地区中、 58 地区 $(69.9 \%)$ で整備に関する記述があった。表 1 は保存計画の主な内容である。最も多いのは歴史的な町並みとの 調和であり、次に住民の安全となっている。材料への配慮を記した ものは 17 地区で、そのうち 6 地区は具体的な材料について述べて いる。また、九州の地区の多くが「近年のアスファルト舗装により 高くなった路面を当初のレベルに下げること」を明記している。独 自の計画が述べられているものに、下郷町大内宿の「街道の路面を 砂利路風に簡易舗装し整備する。」、早川町赤沢の「現在、道路はコ ンクリート・アスファルト舗装となり (中略)、必ずしも周辺の環 境に調和していない。石畳事業を早急に推進する」があげられる。

街路に関する内容は、近隣の地区で同一の記述が多くみられ、具 体性がないものが多く、地区の特徵を踏まえた独自の整備方針を掲 げているところは非常に少ないことが明らかになった。

\section{4. 全国の伝統的建造物群保存地区の街路埔装の現状と問題点}

83 地区が所在する各自治体の担当者宛てにアンケートを送付し、 68 地区（回収率 $81.9 \%$ ）から回答を得た ${ }^{12)}$ 。質問項目は、現在の 舗装材料、舗装における景観的配慮、整備計画、街路の維持管理で ある ${ }^{13) 、 14)}$ 。

\section{(1) 舗装整備の材料 ${ }^{15)}$}

伝建地区の街路で使用した舗装材について、材質からアスファル
ト系、コンクリート、樹脂系、土系、木質系、レンガ系、タイル系、 天然石系の 8 種類に分類し、選択式で複数回答を求めた結果が表 2 である。最も多かったのがアスファルト系の舗装で、57 地区（約 $84 \%$ ）で使用されている。舗装の具体的な種類や製品名を別途記述 してもらったところ、アスファルト舗装では、脱色アスファルト舗 装、カラーアスファルト舗装といった色彩重視のものや、排水性ア スファルト舗装といった機能性重視のものが挙げられた。

アスファルト舗装の次に多いのは天然石系で、27 地区（約 40\%） で使用されている。舗装材の記述では、御影石を使用しているとこ ろが 10 地区あり、10 地区中 4 地区の石の主な産地に中国が挙げら れた。 3 番目はコンクリート系の舗装で、インターロッキング舗装、 洗い出し舗装が挙げられた。「その他」の内容を記述してもらった ところ、地道、白砂、砂を混ぜたアスファルト舗装、いぶしレンガ、 チタン舗装等、地区ごとに様々な舗装材料を使用しており、ブラス 卜処理、表面研磨などを行っている地区もあった。

伝建地区の舗装は、多様な材料を用いて施工されており、色彩や 機能においても工夫が見られ、さらに材料のみならず仕上げで舗装

表 1 保存管理計画における主な街路舗装の方針 $(\mathrm{n}=58)$

\begin{tabular}{|l|c|c|}
\hline \multicolumn{1}{|c|}{ コンセプト } & 地区数 & $\%$ \\
\hline 歴史的（伝統的）風致 (町並み) との調和 & 31 & 53.4 \\
\hline 地域住民の安全 & 19 & 32.8 \\
\hline 材料への配慮 & 17 & 29.3 \\
\hline 路面の高さ & 15 & 25.9 \\
\hline 復元または復原 & 14 & 24.1 \\
\hline
\end{tabular}

表 2 使用している舗装材料

\begin{tabular}{|c|c|c|c|c|c|}
\hline \multirow[t]{2}{*}{ 舖装の種類 } & \multirow[t]{2}{*}{ 舖装 } & \multicolumn{2}{|c|}{$\begin{array}{c}\text { 使用している } \\
\text { 舗装材料 } \\
(\mathrm{n}=68 \text { 、複数回答) }\end{array}$} & \multicolumn{2}{|c|}{$\begin{array}{c}\text { 景観的配慮をした } \\
\text { 舗装材料 } \\
\text { ( }=51 \text { 、複数回答) }\end{array}$} \\
\hline & & 回答数 & $\%$ & 回答数 & $\%$ \\
\hline アスファルト系 & $\begin{array}{l}\text { 普通アスファアルト脱色アスファアルト } \\
\text { なぞ }\end{array}$ & 57 & 83.8 & 25 & 49.0 \\
\hline 天然石系 & & 27 & 39.7 & 20 & 39.2 \\
\hline コンクリート系 & 普通コンクタリートキカララーダンクリー & 17 & 25.0 & 10 & 19.6 \\
\hline 樹脂系 & 天然玉砂利舗装、ゴムチップ舗装など & 7 & 10.3 & 5 & 9.8 \\
\hline 土系 & 地道など & 3 & 4.4 & 2 & 3.9 \\
\hline レンガ系 & & 3 & 4.4 & 3 & 5.9 \\
\hline タイル系 & & 3 & 4.4 & 2 & 3.9 \\
\hline 木質系 & ウッドブロック舖装など & 3 & 4.4 & 0 & 0.0 \\
\hline その他 & - & 9 & 13.2 & 4 & 7.8 \\
\hline 無回答 & - & 1 & 1.5 & 7 & 13.7 \\
\hline
\end{tabular}

表 3 景観的配慮の有無 $(n=68)$

\begin{tabular}{|l|c|c|}
\hline $\begin{array}{c}\text { 景観的配 慮 } \\
\text { の有無 }\end{array}$ & 回答数 & $\%$ \\
\hline 有り & 51 & 75 \\
\hline 無し & 16 & 24 \\
\hline 無回答 & 1 & 1 \\
\hline
\end{tabular}

表 4 舗装デザインのコンセプト $(n=51$ 、複数回答 $)$

\begin{tabular}{|l|c|c|}
\hline \multicolumn{1}{|c|}{ コンセプト } & 回答数 & $\%$ \\
\hline 地区の町並みとの調和 & 43 & 84.3 \\
\hline 観光客が持つ「古い町並」のイメージ & 18 & 35.3 \\
\hline 昔（ある時代）の街路の復元 & 16 & 31.4 \\
\hline 地元の材料の使用 & 5 & 9.8 \\
\hline 視認性（交通安全上の色彩的配慮) & 5 & 9.8 \\
\hline その他 & 2 & 3.9 \\
\hline 無回答 & 1 & 2.0 \\
\hline
\end{tabular}

表 5 舖装材料決定の理由（ $\mathrm{n}=51$ 、複数回答 $)$

\begin{tabular}{|l|c|c|}
\hline \multicolumn{1}{|c|}{ 理由 } & 回答数 & $\%$ \\
\hline 色彩 & 37 & 72.5 \\
\hline テクスチャ & 18 & 35.3 \\
\hline エージング性 & 12 & 25.5 \\
\hline デザイン & 11 & 21.6 \\
\hline その他 & 2 & 3.9 \\
\hline 無回答 & 4 & 7.8 \\
\hline
\end{tabular}

表 7 舗装の現況 $(\mathrm{n}=68)$

\begin{tabular}{|c|c|c|}
\hline 舖装の現況 & 回答数 & $\%$ \\
\hline おおむね良い & 28 & 41.2 \\
\hline 一部悪いところがある & 37 & 54.4 \\
\hline 全体的に悪い & 3 & 4.4 \\
\hline 合計 & 68 & 100 \\
\hline
\end{tabular}

表 6 街路整備に関する基準 $(\mathrm{n}=68)$

\begin{tabular}{|l|c|c|c|}
\hline \multicolumn{1}{|c|}{ 整備計画 } & $\begin{array}{c}\text { 伝統的建造物群保 } \\
\text { 存地区保存計画 }\end{array}$ & その他 & 合計 \\
\hline 有り & 17 & 4 & 21 \\
\hline 無し & \multicolumn{2}{|c|}{ - } & 46 \\
\hline 無回答 & \multicolumn{2}{|c|}{ - } & 68 \\
\hline 合計 & \multicolumn{2}{|c|}{} \\
\hline
\end{tabular}

表 8 舗装材と舗装の現況 $(\mathrm{n}=68)$

\begin{tabular}{|l|c|c|c|c|}
\hline \multicolumn{1}{|c|}{ 舗装 } & アスファルト & 天然石系 & コンクリート & 樹脂系 \\
\hline おお拈良い & 24 & 8 & 7 & 3 \\
\hline $\begin{array}{l}\text { 一部悪い: } \\
\text { 全体的に悪い }\end{array}$ & 33 & 19 & 10 & 4 \\
\hline 合計 & 57 & 27 & 17 & 7 \\
\hline
\end{tabular}


の表情を出しているところもあることが明らかになった。

\section{（2）街路舗装への景観的配慮}

（1）で質問した舗装の中で、景観的に配慮した道路・街路があ るか選択式でたずねたところ、51 地区、75\%が舗装に景観的な配 慮をしていると回答し、無しと答えた地区数を大幅に上回った（表 3 )。

\section{(1)デザインコンセプト}

景観への配慮を「有り」と回答した地区にデザインコンセプトに ついて表 4 の項目から選択式で質問した結果、最も多いのは「地区 の町並との調和」で 43 地区（約 84\%）だった。また、「観光客が 持つ『古い町並み』のイメージ」は 18 地区（約 36\%）あり、昔（あ る時代）の再現」の 16 地区を上回った。地元の材料の使用および、 交通安全上の色彩的配慮である舗装の視認性を選んだ地区は 5 地区 にとどまった。調和やイメージといった曖昧なコンセプトが多数を 占め、本来文化財として検討が必要である時代の再現を考慮してい る地区は少ない結果となった。

\section{(2)景観的配慮のある舗装材料}

景観への配慮を「有り」と回答した地区に、景観的配慮をしてい る整備に使用した材料を複数回答で選択してもらった（表 2 ）。全 体の舗装材の割合と比較するとアスファルト系、コンクリート系の 割合が減少しているが、天然石系の割合はほぼ同じとなっている。

さらに、舗装材料に要求される機能のうち、景観要素である「色 彩」、「デザイン」、「エージング性（年月の経過に伴う周辺環境との 調和・風格の加味)」、「テクスチャ（路面の質感）」から選択式で複 数回答してもらった結果が表 5 である。「色彩」を選んだ地区は 37 地区 $(74 \%)$ と最も多かった。具体的な色を記述してもらったとこ ろ、「町並と調和した色」、「茶系」「グレー」、色」、「地道風」と いった回答だった。次いで多いのがテクスチャ18 地区（約 35\%）、 エージング性 12 地区（約 26\%）、デザイン 11 地区（約 22\%）とい う結果であった。「デザイン」の具体的な内容を記述してもらった ところ「石冨風」や「歩車道分離」などだった。「その他」では「自 然素材の使用」といった回答が見られた。

\section{（3）街路の整備に関する基準}

街路整備における基準、またはガイドラインとなるものの有無を 聞いたところ、46 地区 $(68 \%)$ が「無し」と回答し、「有り」と答え たのは 21 地区（31\%）だった（表 6 ） ${ }^{16)}$ 。「有り」を選択した地区に その名称を回答してもらったところ、21 地区中 17 地区が保存計画 で、その他は富田林市富田林（街なみ環境整備事業）、長崎市東山手、 同南山手 (東山手、南山手地区歴史的環境デザイン設計業務委託 (報 告書)）、柳井市古市金屋（歴史的地区環境整備街路事業）の 4 地区 だった。保存計画に記述がある地区でも「基準はない」と回答して おり、保存計画が有効に機能していない地区があることがわかる。

\section{（4）街路舗装の維持管理状況}

伝建地区内の現在の舗装の状況について、「おおむ拉良い」、「一 部に悪いところがある」、「全体的に悪い」「その他」から当てはま るものを選んでもらった結果が表 7 である。「一部に悪いところが ある」または「全体的に悪い」を選択したのは全体の約 59\%であっ た。舗装材料で見ると、天然石系について「一部悪いところがある」、 「全体的に悪い」の割合が 27 地区中 19 地区と約 $70 \%$ で、他の材料 は40〜60\%だった（表 8 ）。
さらに、「一部悪いところがある」、「全体的に悪い」と答えた地 区にその内容を聞いた結果、クラック、ガタッキ、穴、剥離など物 理的な破損が最も多く 29 地区、修理のコストが 4 地区、修理の痕 跡が目立つなど景観的な問題が 4 地区、その他が 3 地区あった。「全 体的に悪い」の地区と内容は有田町有田の石舗装、八女市八女福島 と日向市美々津の路面の凸凹だった。

伝建地区では舗装に関する基準やガイドラインがない地区が約半 数で、持っていても整備計画の具体的な指針となるものがない場合 がほとんどである。このため文化財の環境の一部として履歷を踏ま えた整備をしているところは少なく、「町並みの調和」や「歴史的 な雾囲気」などあいまいなコンセプトが優先されている現状が明ら かになった。実際に行われている整備は色彩に配慮したアスファル 卜系舗装や天然石系の舗装など椂々で、約半数が物理的な破損など の問題を抱えている現状が明らかになった。

\section{5. 伝統的建造物群保存地区の街路舗装の現況と問題点}

伝建地区の環境の一部としての街路の整備には、(1)環境物件、工 作物としての保護、(2)履歴に基づく材料・工法の復原、(3)別の材料 による履歴の表現、(4)履歴を根拠としない歴史的環境との調和、の 4 つの段階が考えられる。本研究ではアンケートに回答があった地 区の中から、独自の整備を行っており、(1)から (4)に該当する 4 地区 (1)長崎市東山手、南山手 ${ }^{17}$ 、 (2)下郷町大内宿、(3)黑木町黒木、(4) 川越市川越）と、アンケートで特に問題が多いとされた有田町有田 内山を加えた 5 地区を対象に、担当者へのヒアリング ${ }^{18)}$ 及び現地 調查、資料調查を行った。 5 地区の舗装整備の概要は表 9 の通りで ある。表 10 には、それぞれの地区で用いている舗装の耐久性と材 料入手の容易さおよび経済性を評価した。

\section{（1）対象 5 地区の舗装整備と維持管理}

\section{(1)長崎市東山手、南山手一街路が保存対象の事例}

長崎市東山手、南山手は、幕末開港の外国人居留地時代からの 石畳舗装が残されている ${ }^{19)}$ 。東山手、南山手ともに平成 3 年（1991） に重伝建地区に選定された。東山手の道路は昭和 30 年代まで石畳 で舗装されていた。南山手の道路についても、全面石冨であったと

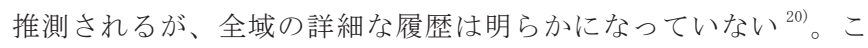
れらの石睤は部分的に現存しており、そのうち東山手で 11 件、南 山手では 36 件の石畳・石段が伝建地区の環境物件に指定され、保 護対象となっている。南山手（図 1) ではどんどん坂（写真 1 ）、 旧グラバー邸東側の道がこれにあたり、ガスの埋設工事などの時に も石畳を一枚ずつ丁寧に剥いで、当初の工法で復帰している。

東山手、南山手それぞれの地区内の街路の計画・設計は「東山手・ 南山手地区歴史的環境デザイン設計業務委託報告書」（平成 3 年）に 基づいて行われている。報告書では整備方針を、洋館を中心とする 歴史的遺産の継承（保全系）、機能を調和させた現代の歴史の創出 (再生系)、先行性・風土を生かした長崎ならではの居留地景観の育 成（育成系）に分類しており、保全系は石畳で主に諫早石、再生系 は諫早石の切石、育生系は白い骨材を用いたホットロールドアスファ ルトが施工されている (写真 2$)^{21)}$ 。担当者へのヒアリングによる と、ホットロールドアスファルトの施工については審議会メンバー の指導により決定したものの、景観的に賛否両論があるということ 


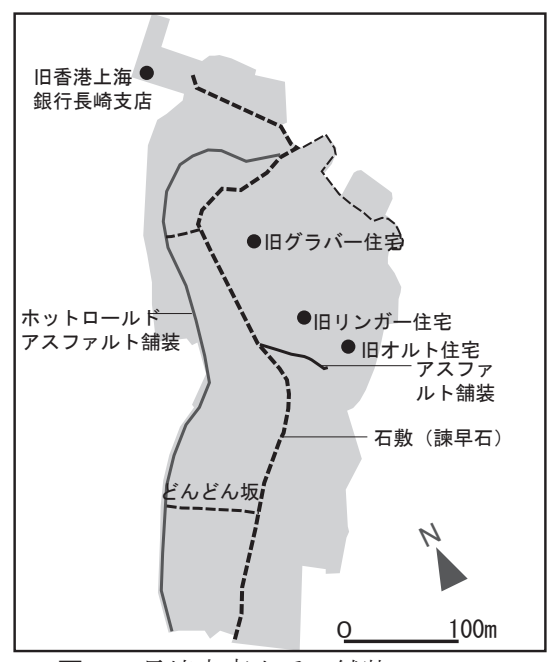

図 1 長崎市南山手の舗装

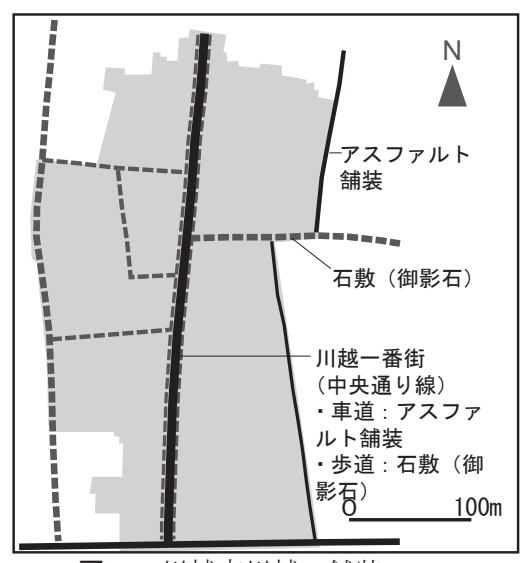

図 4 川越市川越の舗装

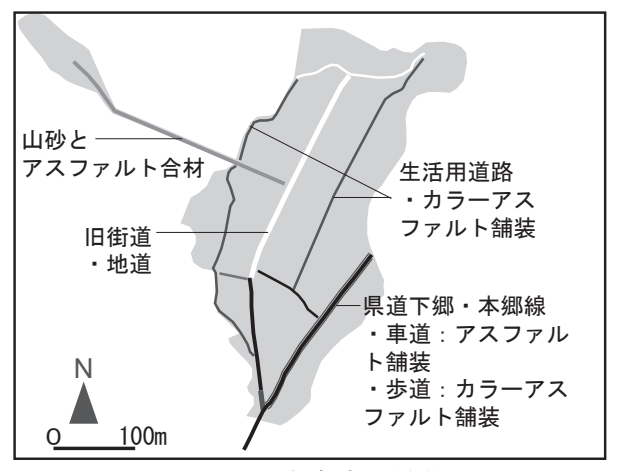

図 2 下郷町大内宿の舗装

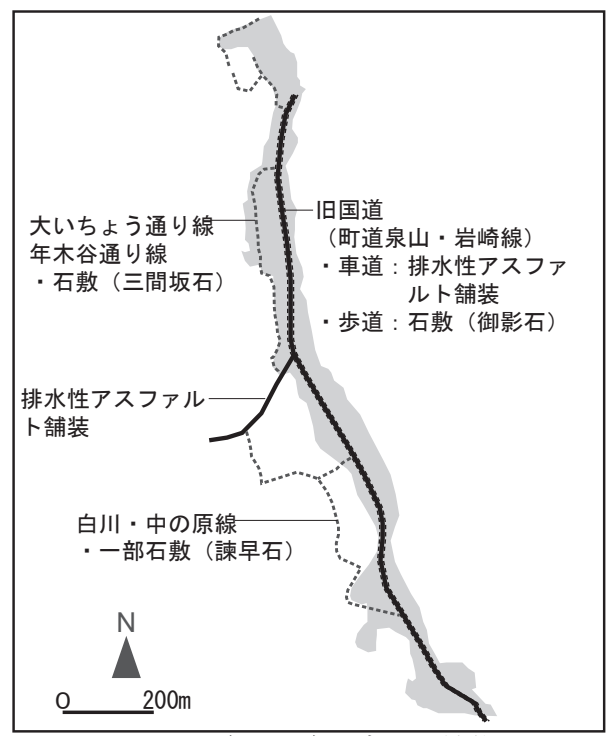

図 5 有田町有田内山の舗装

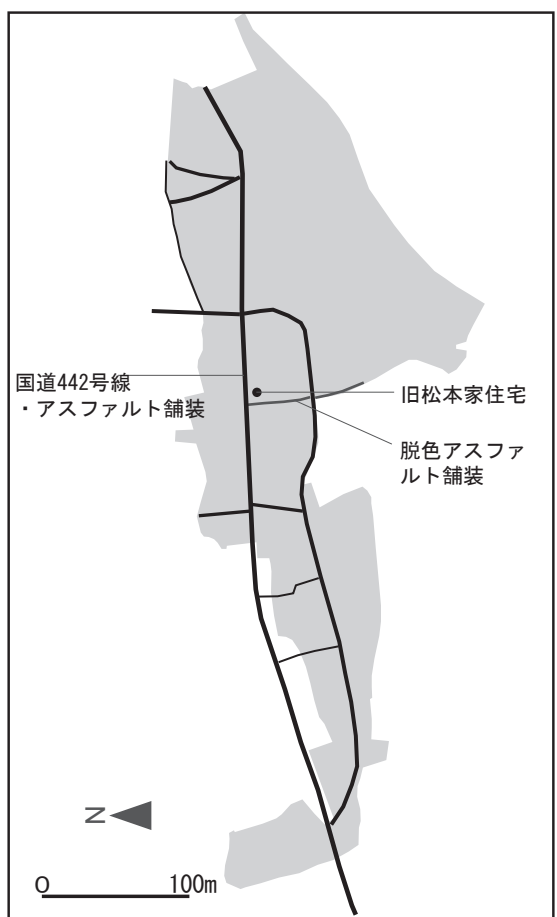

図 3 黒木町黒木の舗装

伝建地区範囲

表 9 対象 5 地区の街路整備の概要

\begin{tabular}{|c|c|c|c|c|c|c|}
\hline \multirow{2}{*}{ 地区名 } & \multirow{2}{*}{ 整備時のコンセプト* } & \multicolumn{2}{|r|}{ 主な整備 } & \multirow{2}{*}{ 産地 } & \multirow{2}{*}{$\begin{array}{r}\text { 而久久性 } \\
* * *\end{array}$} & \multirow{2}{*}{$\begin{array}{l}\text { 材料入手 } \\
\text { - 経済 ** }\end{array}$} \\
\hline & & \begin{tabular}{|l|} 
履歴の保護・復元 \\
\end{tabular} & 町並み創出 & & & \\
\hline \multirow{2}{*}{ 長崎市東山手・南山手 } & \multirow{2}{*}{ 現状維持 } & 石畳・板石（諫早石） & & 長崎県 & $\triangle$ & 0 \\
\hline & & - & |ホットロールドアスフアルト & - & 0 & 0 \\
\hline \multirow{3}{*}{ 下郷町大内宿 } & \multirow{3}{*}{ 歴史的景観を阻害しない } & 地道 & - & 砂 : 福島県 & $\mathrm{O}$ & $\mathrm{O}$ \\
\hline & & - & カラーアスファルト & - & 0 & 0 \\
\hline & & - & 山砂とアスファルト合材 & 山砂 : 福島県 & $\bar{x}$ & $\bar{x}$ \\
\hline 黒木町黒木 & 履歴にもとづく整備 & 脱色アスファルト & & 骨材 : 福岡県、熊本県、長崎県 & 0 & 0 \\
\hline \begin{tabular}{|l|l} 
川越市川越 \\
\end{tabular} & 蔵造りの町並みとの調和 & - & 石疊（御影石） & 中国福建省 & 0 & $\triangle$ \\
\hline \multirow{5}{*}{ 有田町有田内山 } & \multirow{5}{*}{ 有田特有の町並みとの調和 } & - & 石疊（三間坂石） & 佐賀県 & $x$ & $\times$ \\
\hline & & - & 石疊（御影石） & 不明 & 0 & $\triangle$ \\
\hline & & - & 石疊（諫早石） & 長崎県 & 0 & 0 \\
\hline & & - & 排水性アスファルト & - & $\mathrm{O}$ & 0 \\
\hline & & - & タイル & 磁器 : 佐賀県 & 0 & $\triangle$ \\
\hline
\end{tabular}

（*コンセプトは担当者へのヒアリングによる。 ***耐久性、材料入手·経済性は担当者へのヒアリングおよび現地調查による評価。○:良い $\triangle:$ : 部悪い、メ:悪い)

表 10 対象 5 地区の保存計画および街路事業

\begin{tabular}{|c|c|c|c|c|c|c|}
\hline \multirow{2}{*}{ 地区名 } & \multirow{2}{*}{ 重伝建選定 } & \multirow{2}{*}{$\begin{array}{c}\text { 保存計画における街路・舖装 } \\
\text { に関する記述 }\end{array}$} & \multicolumn{3}{|c|}{ 主な街路事業 } & \multirow{2}{*}{ 指針等 } \\
\hline & & & 名称 & 調査年 & 整備年 & \\
\hline 長崎市東山手・南山手 & 平成 3 年 & \begin{tabular}{|l|} 
基本は現状のまま。変更の場合は歴 \\
史的景観に調和した石畳道路等。
\end{tabular} & 歴史的地区環境街路整備事業 & 昭和 59 年 & 不明 & \begin{tabular}{|l} 
東山手・南山手地区歴史的環境 \\
デザイン設計業務委託報告書
\end{tabular} \\
\hline 下郷町大内宿 & 昭和 56 年 & \begin{tabular}{|l|} 
生活用道路の取り付け。街道を砂利 \\
路風に簡易舗装
\end{tabular} & ウォーキング・トレイル事業 & 不明 & 平成 8 年 & なし \\
\hline 黒木町黒木 & 平成 21 年 & \begin{tabular}{|l|} 
履歴を考慮した工法、歩行者の安全 \\
に配慮した整備
\end{tabular} & 街なみ環境整備事業 & 平成 15 年 & 平成 17 年 & なし \\
\hline \begin{tabular}{|l|} 
川越市川越 \\
\end{tabular} & 平成 11 年 & 歴史的風致の維持、增進 & 歴史的地区環境街路整備事業 & 昭和 60 年 & 平成 2 年 & なし \\
\hline 有田町有田内山 & 平成 3 年 & $\begin{array}{l}\text { 拡幅の歴史的経緯の表現。既存の石 } \\
\text { 積、石敷の活用による伝統的町並み } \\
\text { にふうわししいの。 }\end{array}$ & 歴史的地区環境街路整備事業 & 昭和 63 年 & 平成元年 & $\begin{array}{l}\text { 歴史的地区環境整備街路事業調 } \\
\text { 查報告書 }\end{array}$ \\
\hline
\end{tabular}




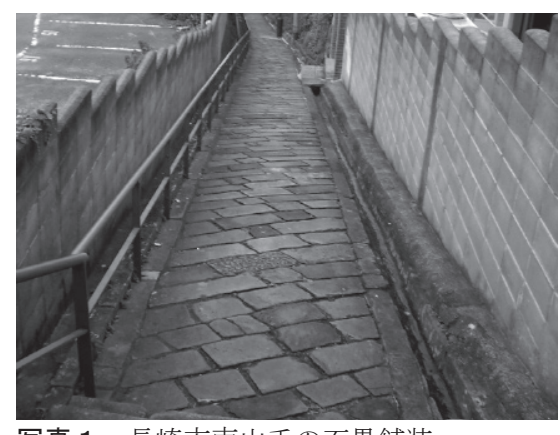

写真 1 長崎市南山手の石畳舗装

(どんどん坂)

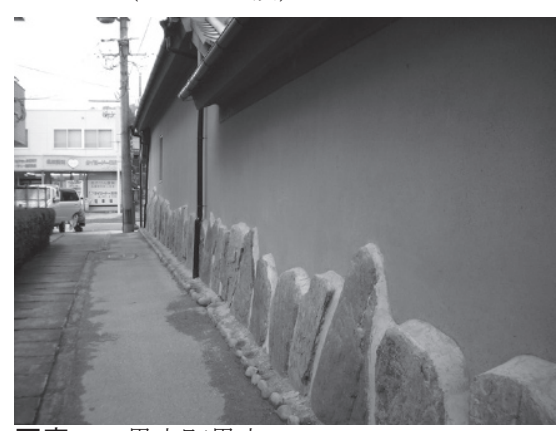

写真 4 黒木町黒木の 脱色アスファルト舗装

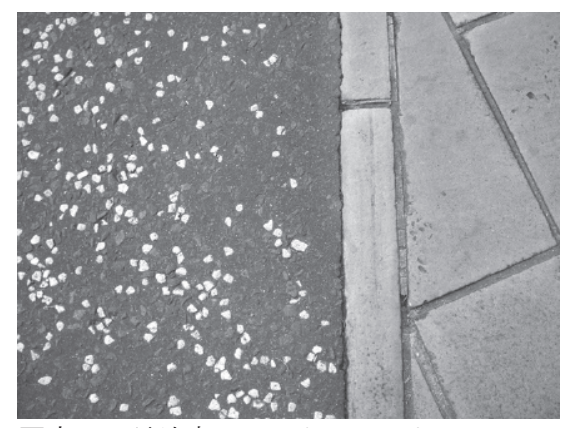

写真 2 長崎市のホットロールド アスファルト舗装 (左)

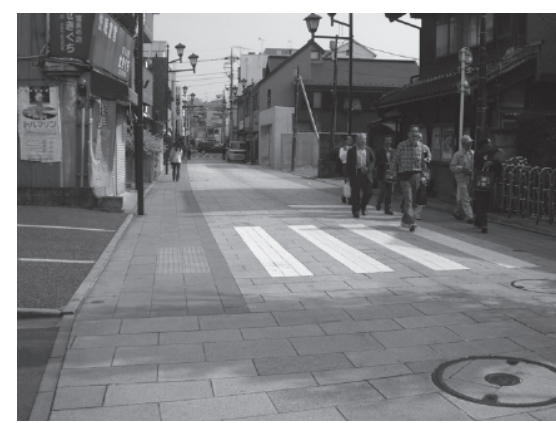

写真 5 川越市川越の御影石による舗装

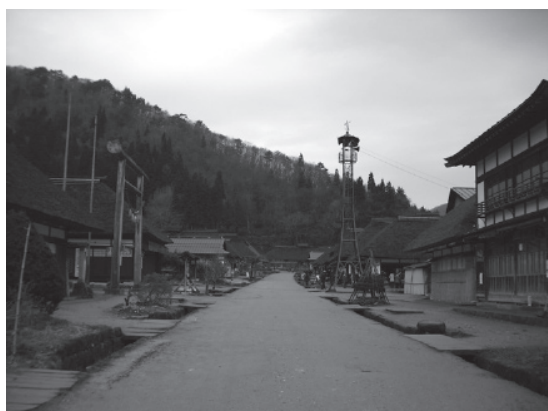

写真 3 下郷町大内宿の地道

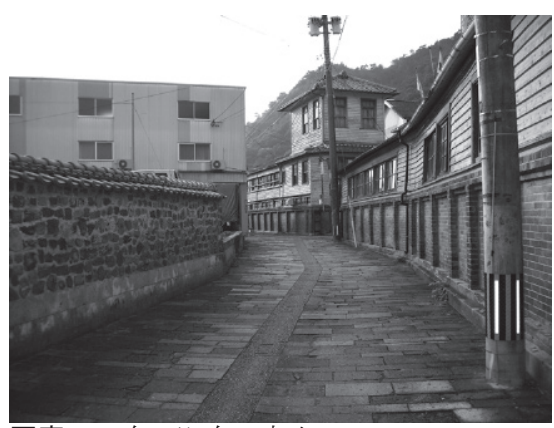

写真 6 有田町有田内山の

三間坂石による舗装
である。諫早石について歩行に支障はなく、地域住民にとっても昔 から慣れ親しんでいるため違和感はないが、車両が進入する街路で は目地の破損やアスファルトでの応急処置の跡が目立つなどの問題 があるという。

東山手、南山手では環境物件に指定された石畳は文化財としての 保存が行われており、履歴の不明な場所では同じ諫早石でも切石に してオリジナルとの差をつけている点で工夫が見られる。

\section{(2)下郷町大内宿一地道復原の事例}

大内宿は寄棟茅莫の家屋の並ぶ宿場町で、昭和 56 年（1981）に 重伝建地区に選定された。旧街道は下野街道として平成 14 年 (2002) に史跡指定された。旧街道には明治期まで中央に生活用の水路が 通っていたが ${ }^{22)}$ 、昭和 44 年（1969）にアスファルト舗装が行われ 水路を道の両側に移動させた。平成 10 年（1998）に中央の水路の 復原について地域住民の協議が行われたが、水路の一本化について は次世代に託すということで決定した。その後、平成 11 年 (1999) の伝統的建造物群保存地区保存審議会において舗装については以前 の地道に復原することが決定し、平成 12 年 (2000) にはアスファ ルトが撤去されて地道となり、宿場の歴史的な共同生活の場が復活 した (写真 3$)^{23)}$ 。旧街道以外の街路では、生活用道路および県道 の歩道部分はカラーアスファルト舗装、地区の西にある神社への道 は山砂とアスファルト合材が施工されている（図 2)。

旧街道には地元で採れる赤土を使用し、土間の仕上げに用いられ るたたきの工法が採用された。当初その耐久性が懸念されたが、現 在は土が固く踏み固められ、埃もほとんど立たないという。このよ うな道路が良好な状況で維持されているのは以下のような理由があ る。まず、車両乗り入れ規制である。 8 時から 17 時まで車両進入 を禁止し、原則歩行者のみが使用寸る。また、町や住民によるこま めな維持修繕によって水溜りやわだちはほとんどない。大内宿は豪 雪地帯であるため、旧街道についても地元の業者に委託して除雪車
による除雪を行っている。地面にある程度の厚さの雪を残して除雪 することで、土は削られず地道への影響はないそうである。

大内宿では街路舗装が復原され、車の進入規制や地域住民の理解 と舗装材に対応した日常の管理によって維持されている。

\section{(3)黒木町黒木一街路の履歴を新たな舗装材で表現した事例}

黒木町黒木は近世前期に成立した在郷町で、近世後期以降の居蔵 造の重厚な町家が残っている。正徳 4 年（1714）には現在の町並み や水路の骨格ができた。上町から下町までの通りの両側に梅の木と 柘榴の木が植えられ「全国でも類稀な古く黒みたる特異な町並み」 であると柳田國男が印象を記している ${ }^{24)}$ 。昭和 48 年から、地区の 中心を走る県道八女小国線（現国道 442 号線）の拡幅が行われた。 重伝建地区に選定されたのは、平成 21 年 (2009) である。黒木では、 町の履歴に基づき、かつて地道であったことが明らかな街路は「地 道風の舗装」として脱色アスファルト舗装を行い、新しく開削され た道や履歴にない道は通常の黒いアスファルト舗装をして差別化を 図っている（図 3、旧松本家横の街路、写真 4)。

特に配慮しているのは、ガス管や水道管を埋設した際、同様の施 工・材質で再び舗装できるかどうかである。そのため材料を容易に 入手できるような整備、管理の体制づくりを行っている。履歴を異 なる材料で表示した脱色アスファルト舗装は目立たない色で、維持 管理における問題は今のところない。

黒木町では維持管理まで考慮した材料と施工の選択により、問題 は見られない。旧松本家住宅の壁の色とも違和感が無く、ヒアリン グによると住民、観光客の反応は概礽好評だという。

\section{(4)川越市川越一町並み調和型の事例}

川越は明治 26 年（1893）の大火後に建てられた蔵づくりの家屋 によって重厚な町並みが形成された。昭和 40 年代後半からは市民 による保存運動が始まり、昭和 61 年 (1986) には、自主協定であ る「まちづくり規範」を作成しまちづくりの実践をしてきたことは 
知られている ${ }^{25)}$ 。重伝建地区に選定されたのは後の平成 11 年 (1991) である。正確な記録が無いものの、当初の舗装は砂の地道であっ たと推測され、その後アスファルト舗装されたが、平成 3 年度から 19 年度にかけて、御影石による舗装に徐々に変化した（写真 5 )。 中央を通る川越一番街は平成 4 年に電線の地中化、平成 19 年に歩 道の拡幅と石畺舗装が行なわれた（図 4 ）。現在の石畳は履歴とは 関係がなく、ヒアリングによると御影石の材料選定の理由は景観性 で、蔵の持つ石のイメージに合わせて中国福建省の白御影と黒御影 を使用し、人を引き込むデザインを心がけたという。この整備は全 国街路事業コンクールで受賞するなど、高い評価を受けている。

御影石はアスファルト舗装よりも価格は高いが、材料の入手は容 易である。しかし、色彩やテクスチャが微妙に異なるため、現在は 整備時に多めにストックして補修に使用しているという。御影石は 污れが落としにくい、ガタツキが起こるなどの問題はあるが、通行 に支障をきたすことはない。車両が通るところでは不具合が生じや すいが、その都度補修を行っている。

川越では魅力あるまちづくりが重伝建選定に先行し履歴によらな い石舗装が行われた。評価も高く、維持管理も出来ている点におい ては問題が無い。

\section{(5)有田町有田内山一地区のイメージを強調した整備の事例}

佐賀県西部にある有田は、江戸初期に陶磁器産業のために新し く形成されたまちである ${ }^{26)}$ 。平成 3 年（1991）に重伝建地区に選定 された。残されている映像資料等によると地区の街路はかつて馬車 が行きかう地道であったそうである。旧国道は軍事用道路としての 利用があり、町道も昭和 47,8 年頃にアスファルト舗装が順次行わ れたとのことである。現在の舗装は平成元年以降に整備されたもの で、拡幅の経緯は表現されたが、おもにデザイン性や町並みとの調 和を重視している。その結果、旧国道は歩道が御影石、車道が透水 性アスファルト、散策のための道のうち、大いちょう通り線、年木 谷通り線は隣接市で産出する三間坂石、白川・中の原線には長崎の 諫早石、交差点には陶磁器製品のタイルなどさまざまな材料が用い られた（図 5 )。

特に問題が起こっているのは、三間坂石による舗装である（写 真 6 )。当初、歩行者専用の道路として整備されたが、施工当時よ りも一般家庭の自動車所有台数が増えたために石材の痛みがひどく なっている。一番初めに施工したトンバイ塀の裏通りは三間坂石を 貼ってから 20 年以上たつが、段差やがたつきがあちこちで見られ、 住民からは段差でつまずくという苦情がでている。施工当時はここ までの舗装状況の悪化は予想していなかったそうである。強度を増 寸ために、業者が石材をたたいて強度を調べ、強い石のみを吟味し て用いたが、自動車の荷重により破損したとのことであった。三間 坂石の価格が高いこと、産出量が減って入手が困難になっているこ とから維持管理が困難になっている。

整備時に維持管理を考慮せず、デザイン性を重視した結果、さま ざまな問題が生じているといえる。

\section{（2）保存計画にみる街路整備方針（表 10）}

長崎市東山手、南山手では、環境物件は修理基準に従うこと、そ の他「街路及び散策道の景観的整備を行う。」としており、新たな 整備に関寸る基準はなく、実際には別の担当部署の事業として作成 された報告書が基準になっている。大内宿は「砂利道風に簡易舗装
し整備する」とあるが、実際には議論を経て地道を復原した。黒木 町黒木では「道路面の舗装、側溝の改良については、保存地区の履 歴を考慮した工法、材料等及び歩行者の安全性に配慮した整備を進 め、歴史的風致の維持・回復に努める」とあり、整備の内容もこれ に従ったものとなっている。川越市川越は「安全で快適に歩ける街 路整備を進める」としており、具体的な材料や履歴に関する言及は ない。有田町有田内山では道路の復旧・修景の項目で「拡幅前の道 路形態を調查して拡幅の歴史的経緯を路面敷石等により表し、伝統 的町並夕に相応しいものとして修景する」、「既存の石敷を活用して 伝統的町並みに相応しいものとする。」具体的に書かれている。「拡 幅の歴史的経緯」は歴史的地区環境街路整備事業のデザインコンセ プトに受け継がれたが、材料、工法についての復原の配慮はなく、 結果としてさまざまな材料が使用された。

保存計画には具体的な記述がないため、従っていても実際の材料 の選択や維持管理において問題が起こる場合が多いと考えられる。 また、大内宿のように内容が具体的であっても実際の整備とは異な る場合もある。保存計画への街路舗装の指針の記述の方法をより具 体性で実効性があるものにする必要が示唆される。

\section{(3) 整備事業}

5 地区の街路舗装の整備事業は表 9 の通りである。5 地区中 3 地区が部分的に歴史的地区環境街路整備事業（以下「歴みち事業」） によって舗装整備しており、その他も街なみ環境整備事業、ウォー キング・トレイル事業など国土交通省の補助事業を用いている。大 内宿を除く 4 地区では街路事業の開始が重伝建地区選定に先行して いる。ヒアリングによると、整備費用の補助はすべての事業におい ておよそ半分であり、整備後の維持管理費は全て自治体が負担して いるという。

また、長崎市では街路事業による整備は一部のみであり、現在は 「東山手・南山手地区歴史的環境デザイン設計業務委託報告書」に 基づいた市の財源による整備が中心となっている。また有田町で も、現在は歴みち事業が停止しており、町が独自に事業時の調查報 告書を元に舗装の維持・修繥を行っている。

\section{（4）街路整備における主体の連携}

各地区の街路整備に携わる部署は表 11 の通りである。舗装整備 には、計画、設計、施工、維持、管理という段階的な流れがあるが、 伝建地区により一貫して行う場合（長崎市、有田町、下郷町）と、 それぞれ担当部署が違う場合（川越市、黒木町）がある。伝建地区 内に関寸る業務は通常教育委員会の文化財担当の部署が行うが、長 崎市では、文化財課が文化財保護の視点から許可や助言・指導を道 路公園総務課に対して行っているのに対し、他の 4 地区は街路整備 については文化財担当者の積極的な介入がない。

また、舗装整備の計画段階や改修時に、伝統的建造物群保存地区 保存審議会や景観審議会での審議を経て学識経験者の意見を取り入

表 11 対象 5 地区の舗装関係の担当部署

\begin{tabular}{|c|c|c|c|c|}
\hline 地区名 & 計画 & 設計 & 維持 & 管理 \\
\hline 長崎市東山手・南山手 & \multicolumn{4}{|c|}{ 道路公園総務課 } \\
\hline 下郷町大内宿 & \multicolumn{4}{|c|}{ 建設課 } \\
\hline 黑木町黒木 & \multicolumn{2}{|c|}{ 教育委員会 } & \multicolumn{2}{|l|}{ 建設課 } \\
\hline 川越市川越 & 都市計画課 & 街路課 & $\begin{array}{c}\text { 道 路 環 境整 } \\
\text { 備課 }\end{array}$ & $\begin{array}{c}\text { 建 設管 理 } \\
\text { 課 }\end{array}$ \\
\hline 有田町有田内山 & \\
\hline
\end{tabular}


れている地区が多い。一方、地域住民の意見について、それぞれの 地区に保存団体・まちづくり団体があるものの、舗装整備に関する 協議を行っているのは川越市のみである。その他の地区は、整備に 住民の意見が直接反映される体制ではない。

\section{6. まとめ}

保存計画の記述、アンケート調查および事例調查の結果から以下 の点が考察された。

環境物件、および工作物として街路舗装を保護する場合は、原則 として現状維持であり、長崎市のように整備や修理時はそのままを 保存すれば問題はない。復原については大内宿のように、車両の乗 り入れを制限し地域の協力を得て維持管理を継続することが可能だ が、現在の利用と地域住民の生活のバランスへの配慮が必要であ る。これらの指定物件と、それ以外の街路の整備は、デザインを変 えてオリジナルを明確にするなどの工夫が有効である。また、履歴 を別の材料で表現する場合には、後述するように材料への配慮が必 要である。川越では 15 年という時間をかけて、計画的に街路整備 したことが高い評価に繋がっている。しかし、重伝建選定に先駆け て整備が進められたため、履歴に基づかない石舗装となっており文 化財保護の視点からは、伝建地区の当初の街路について、石敷きで あったかのような誤解を与える可能性がある。

街路舗装の材料について、アンケートの結果からは、多くの地区 で物理的な破損などの問題を抱えていることが明らかになった。他 の材料に比べて石舗装の問題の割合が高いことからも、自動車の通 行があるところでの石舗装は避けたほうがよく、履歴にしたがって 石舗装にする場合には、自動車の通行規制などをあわせて考慮する 必要がある。街路事業を取り入れる場合、補助が出るのは施工まで で、その後発生する維持管理費は各自治体が負担しなければならな い。そのため地区の財政的な実情と、現在さらには将来の交通状況、 さらに舗装材料のコストや材料入手をふまえ、高価な材料や強度の ない材料の使用は避ける心゙きである。維持管理を前提とした材料の 選定が必要である。

舗装の指針については、保存計画での言及はあるが具体的ではな いことに加え、それらが基準として十分に活かされていない現状が 明らかになった。 5 地区の事例では、明確な方針をうち出している 黒木町黒木以外は、復原された大内宿でも委員会の委員による強い 発言によって整備が決定するなど、具体的なデザインや材料の決定 は計画時の担当者や委員会にゆだねられている状況である。また、 街路の整備はおもに国土交通省の事業により行なわれ、各部署の連 携の方法も一様ではない。

街路舖装は、履歴を確認した上で、現在の交通状況を踏まえて材 料や工法の復原が可能かどうか、可能でない場合および履歴が確認 できない場合には、「歴史的な町並みに調和」させるのではなく、 例えば、「履歴にない材料を使用する場合は、（脱色）アスファルト 舗装とする」等、具体的な提示が有効であると考えられる。

\section{注および参考文献}

1）景観デザイン研究会：景観用語事典、彰国社、p. 174、1998

2）国土交通省 都市・地域整備局：景観形成ガイドライン「都市整備に関する 事業」(案)、p. 28、2005

3）土木学会:舗装工学ライブラリー6 街路における景観舗装 - 考え方と事例一、 丸善、p. 74、2007

4）全国伝統的建造物群保存地区協議会 : 歴史の町並、p.2、2008

5)（財）世界遺産白川郷合掌造り保存財団：白川郷合掌造り集落の景観、 pp. 7-9、2001

6) 陳 偉嬌他 2 名：日射を受けた常時濡れ面での蒸発冷却効果及び蒸発性能の 劣化：吸水機能を有する透水性アスファルト舗装材の蒸発泠却効果に関す る研究 (その 2)、日本建築学会環境系論文集 (610)、pp. 27-34、2006.12

7) 大貝 彰他 2 名：中心市街地における安全性と景観性の両面からみた歩行 空間評価 豊橋市都市景観形成地区を事例として、日本建築学会技術報告集 No. 20、pp. 313-318、2004

8）堤 信一郎他 1 名: 伝統的集落における道路整備による景観の復元と維持に 関する研究 竹富町竹富島重要伝統的建造物群保存地区を事例として、日本 建築学会大会学術講演梗概集 F-1、pp. 509-510、1998

9）岩崎 直子他 3 名：重要伝統的建造物群保存地区における街路景観に関する 調査研究、日本建築学会大会学術講演梗概集 F-1、pp. 839-840、2001

10）道尾 淳子他 1 名：歴史地区における歩行者空間の成立要因に関する研究 重要伝統的建造物群保存地区 27 地区を事例として、日本建築学会大会学術 講演梗概集 F-1、pp. 519-520、2007

11）街路舗装が対象であるため、石段のみの場合は除外した。

12）伝統的建造物群保存地区の舗装担当部署については事前に電話またはH P で確認を行った。その結果、回答のあった６８地区中教育委員会などの文化 財担当部署が 55 地区、建設課、観光課などその他の部署が 11 地区、不明が 2 地区だった。

13）質問は主に選択式で回答を求め、選択肢にない場合は「その他」を選択し てもらい別途記述欄を設けた。さらに個別の整備内容などについては記述式 とした。

14）舗装は「道路構造令」で第 1 種〜第 4 種に分類され一般的な技術基準が定 められている。伝統的建造物群保存地区の道路は第 3 種または第 4 種に該当 するが、これらの分類はかならずしも景観の差異には結びつかないため、本 研究では考慮していない。また、アンケートでは概要を把握し、基礎的なデ ータを得ることを目的としているため、国道、市道などの道路の管轄および 種別については区別していない。

15）使用されている舗装材の種類を確認寸るための設問で、使用している面積 や歩道、車道などは区別していない。

16）担当者がガイドラインとして実際に使用しているものを問うているため、 保存計画に記載があっても回答されない場合がある。

17）長崎市は 2 地区あるが、担当部署、事業等が同じであるため、 1 地区とする。 18〉ヒアリングの詳細は下記の通り

\begin{tabular}{|c|c|c|}
\hline 地区名 & 調査日 & ヒアリング \\
\hline 川越市川越 & 平成 20 年 10 月 22 日 & $\begin{array}{l}\text { 川越市建設部街路課 } \\
\text { 都市計画部都市景観課 }\end{array}$ \\
\hline $\begin{array}{l}\text { 長崎市東山手． } \\
\text { 南山手 }\end{array}$ & 平成 20 年 11 月 25 日 & 長崎市文化観光部文化財課 \\
\hline 有田町有田内山 & 平成 20 年 11 月 26 日 & 有田町役場農林建設課 \\
\hline 黒木町黒木 & 平成 20 年 11 月 28 日 & 黒木町教育委員会事務局 \\
\hline 下郷町大内宿 & 平成 20 年 12 月 9 日 & $\begin{array}{l}\text { 下郷町教育委員会 } \\
\text { 下郷町役場事業課建設班 }\end{array}$ \\
\hline
\end{tabular}

19）古くは文久元年の文書に舗装されているとの記述が見られる。（長崎市教 育委員会：長崎居留地伝統的建造物群保存対策調査報告書 p. 174、1989)

20）長崎市教育委員会：長崎居留地伝統的建造物群保存対策調査報告書、 
p. $59 、 1989$

21）長崎市：東山手・南山手地区歷史的環境デザイン設計業務委託報告書、 p. 59、1991

22) 明治期までの中央の用水路は平成 11 年の発掘調査によって確認された。(下 郷町教育委員会: 宿場大内 茅莫きの家並み 旧用水路跡発掘調査報告調査 報告 p. $1 \sim 3 、 2000)$

23）下郷町・下郷町教育委員会 : 宿場大内 茅莫きの町並夕 下拫町大内宿伝 統的建造物群保存地区見直し調査報告書、p. $62 、 1988$

24）柳田國男：豆の葉と太陽、創元社、p. 72、1941

25）埼玉県・川越市：未来に生きる町並み、p. 4、2000

26）有田町：有田内山地区 歷史的地区環境整備事業調査報告書、p. 57、1988

（2010年 4 月 5 日原稿受理，2010年 7 月29日採用決定 